\title{
Factors Affecting Presbycusis on Audiogram Overview at H. Adam Malik General Hospital Medan
}

\author{
Frenky Sorimuda Manullang1), Adlin Adnan²), Delfitri Munir²) \\ 1)Faculty of Medicine, Universitas Sumatera Utara, Medan, Indonesia \\ ${ }^{2)}$ Department of Ear, Nose and Throat Health Sciences-Head and Neck Surgery, \\ Faculty of Medicine,Universitas Sumatera Utara, Medan, Indonesia
}

\section{ABSTRACT}

Background: Presbycusis incidence is thought to have a relationship with hereditary factors, metabolism, atherosclerosis, noise and lifestyle. The presbycusis classification consists of Sensory (outer hair-cell), neural (ganglion-cell), metabolic (strial atrophy), and conductive cochlea (stiffness of the basilar membrane). Factors that influence presbycusis include age, gender, genetics, hypertension, gout, diabetes mellitus, hypercholesterolemia, noise exposure, and smoking. This study aims to determine the factors that influence presbycusis on the audiogram image at H. Adam Malik Hospital Medan.

Subjects and Method: This study was an analytical study with a cross sectional design in elderly patients at the polyclinic. The study was conducted in November to December 2019. The dependent variable was the incidence of presbycusis. The independent variables were uric acid levels, blood sugar levels, smoking habits, hypercholesterolemia, and hypertension. Data were analyzed by using chi square test.

Results: The prevalence of presbycusis in the 45-59 years age group was 39 people (54.2\%) and the 60-74 years age group was
33 people (45.8\%). In this study, it shows that male respondents are more than female respondents, where the number of men is 58 people (80.6\%) and women are 14 people (19.4\%). Based on presbycusis type, there were 33 (45.9\%) people (normal), 18 (25\%) people (strrial type), 7 (7.9\%) people (neural type), 7 (7.9\%) people (sensory type), 7 (7.9\%) people (cochlear type). High sugar content $(\mathrm{OR}=3.33 ; 95 \% \mathrm{CI}=1.81$ to $6.13 ; \mathrm{p}<0.001)$, uric acid levels $(\mathrm{OR}=2.36 ; 95 \% \mathrm{CI}=1.19$ to 4.70; $\mathrm{p}=0.005)$, total cholesterol levels $(\mathrm{OR}=$ 3.33; $95 \% \mathrm{CI}=1.81$ to $6.13 ; \mathrm{p}<0.001)$, and smoking $(\mathrm{OR}=1.90 ; 95 \% \mathrm{CI}=1.21$ to $2.97 ; \mathrm{p}=$ 0.016) increased the risk of presbycusis.

Conclusion: High sugar levels, uric acid levels, total cholesterol levels, and smoking habits increase the risk of presbycusis.

Keywords: presbycusis, audiogram image

\section{Correspondence:}

Frenky Sorimuda Manullang. Faculty of Medicine, Universitas Sumatera Utara, Medan, Indonesia. Email: manulangdrfrenky@gmail.com. Mobile: +62-8126394-830.

\section{Cite this as:}

Manullang FS, Adnan A, Munir D (2021). Factors Affecting Presbycusis on Audiogram Overview at H. Adam Malik General Hospital Medan. J Epidemiol Public Health. 06(01): 14-22. https://doi.org/10.26911/jepublichealth.2021.06.01.02.

cc (i) (2) Indonesian Journal of Medicine is licensed under a Creative Commons

\section{BACKGROUND}

Sensorineural hearing loss or presbycusis is often associated with age and is the most common cause of hearing loss in older people. Presbycusis consists of four types, namely: sensory type, neural, metabolic or stria, and cochlear conduction. Presbycusis is a decrease in hearing function in line with the aging process. The audiogram shows a bilateral and symmetrical picture of hearing loss that begins to occur at high notes and is sensorineural in nature with no underlying abnormalities other than the 
aging/ degenerative process in general (Roland, 2014; Nuryadi et al., 2017).

Presbycusis can occur due to degenerative changes in the inner ear resulting in decreased ventral nucleus ganglion cells of the ventral cohlea, medial geniculate, and complex superior olivary resulting in decreased cell function. In addition, there can also be an accumulation of metabolic products and a decrease in enzyme activity that plays a role in decreasing cell function (Lee et al., 2006; Suwento and Hendarmin, 2007; Roland, 2014). Factors that influence the occurrence of presbycusis include age, gender, genetics, hypertension, diabetes mellitus, hypercholesterolemia, noise exposure, and smoking (Kim et al., 2010).

Presbycusis is one of the hearing disorders that is of concern to the National Committee for Deafness and Hearing Loss Management (Komnas PGPKT). The aim of the program is to reduce the incidence of presbycusis by 90\% by 2030 (Muyassaroh, 2012; Kim et al., 2010). The increase in disease progression makes it more difficult for sufferers to determine the source of the sound (Suwento and Hendarmin, 2007; Roland, 2017).

The prognosis in prebikusis patients is still poor, where presbycusis sufferers will experience progressive hearing loss, where the average hearing loss is around 0.7-1.2 dB per year, depending on the patient's age (Lalwani, 2008). This study aims to determine the factors that influence presbycusis on the audiogram image. Therefore, based on this background, researchers are interested in doing this research due to the lack of data or research information about this presbycusis picture in the city of Medan or even in Indonesia.

\section{SUBJECTS AND METHOD}

\section{Study Design}

This study was conducted with an analytical research study with a cross sectional study design. The aim is to analyze the factors affecting presbycusis patients based on the audiogram image. The study was conducted at the Geriatric Polyclinic at Haji Adam Malik Hospital Medan and was carried out in November 2019-December 2019.

\section{Population and Sample}

The study population was all patients seeking treatment at the geriatric clinic of Haji Adam Malik Hospital Medan. Patients selected as samples were patients who met the inclusion and exclusion criteria. The sample size estimate is determined using the Lemeshow formula. The results of the calculation of the sample size above, 72 patients are needed.

The inclusion criteria in this study were: Age $>50$ years and agreed to participate in the study by signing the informed consent. While the exclusion criteria in this study were: patients who were not cooperative and patients with incomplete data.

\section{Variables}

The variables studied in this study consisted of independent variables (independent variables), namely: uric acid levels, cholesterol levels, smoking habits, blood sugar levels (diabetes mellitus) and hypertension and the dependent variable (dependent variable), namely presbycusis.

\section{Operational Definition of Variables} Diabetes mellitus (DM) is a heterogeneous metabolic disorder characterized by hyperglycemia (increased blood sugar levels). Data collection of blood sugar levels was measured using the Easytouch tool, with measurement results that are normal (<200 mg/ dl) and DM ( $\geq 200 \mathrm{mg} / \mathrm{dl}$ ). The measurement scale is continuous, but for analysis purposes it is transformed into a 
dichotomous, coded o for Normal and 1 for DM.

Hypercholesterolemia is a condition with an increase in total blood cholesterol levels above normal limits. Data collection of total cholesterol levels was measured using the Easytouch tool, with the measurement results being normal $(<200 \mathrm{mg} / \mathrm{dl})$ and hypercholesterolemia $(\geq 200 \mathrm{mg} / \mathrm{dl})$. The measurement scale is continuous, but for analysis purposes it is changed to dichotomous, coded o for Normal and 1 for hypercholesterolemia.

Hyperuricemia is an increase in uric acid levels above normal limits. Data collection of uric acid levels was measured using the Easytouch tool, with the measurement results being normal measured by men $<7$ $\mathrm{mg} / \mathrm{dl}$ and women $<6.3 \mathrm{mg} / \mathrm{dl}$. The scale of measurement was continuous, but for analysis purposes it was changed to dichotomous, coded o for Normal and 1 for hypouricemia.

The smoking habit is in the form of the number of cigarettes that are smoked in one day. Data collection was carried out by means of a questionnaire. Measurement scales were categorized, coded o for no smoking and 1 for smoking.

\section{Instruments}

Otoscopy, namely otoscopicexamination, is to assess the condition of the ear canal and tympanic membrane. This examination uses an otoscope, when we insert the otoscope in the ear canal, we will inspect the tympanic membrane by assessing, light reflex, membrane integrity (intact, central perforation, marginal, tweaking), color (clear, gloomy, hyperemic), other abnormalities. lateral to the tympanic membrane (bullae, polyps, cholesteatoma), abnormallities in the medial tympanic membrane (fluid, bubbled water, hematoma, mass).

Audiometry is a practical test to detect significant hearing loss. The tests required for audiometric screening must be clear, inexpensive and acceptable to sufferers (Gates \& Mills, 2005). Audiometric examination consisted of air conduction (AC) and bone conduction (BC). To check the threshold with air conduction (AC) can be done namely first by putting the headphones in accordance with the sides of the ears. The right is red, the left is blue, do sound recognition to the patient by giving a frequency stimulus of $1000 \mathrm{~Hz} 30 \mathrm{db}$. If there is no response, increase the amplitude until a stimulus response is obtained, the stimulus is given 1-2 seconds, the amplitude given depends on the patient's response to the previous stimulus. When the patient responds to the stimulus, the amplitude is decreased by $10 \mathrm{~dB}$. If the patient does not respond, then drop $5 \mathrm{~dB}$, the stimulus is given respectively at a frequency of 1000 $\mathrm{Hz}, 2000 \mathrm{~Hz}, 3000 \mathrm{~Hz}, 4000 \mathrm{~Hz}, 6000 \mathrm{~Hz}$ and $8000 \mathrm{~Hz}$. Then a retest was carried out at a frequency of $1000 \mathrm{~Hz}$ followed by a frequency of $500 \mathrm{~Hz}$ and $250 \mathrm{~Hz}$, the hearing threshold was determined by the amplitude that the patient could detect at least 2 out of 3 giving the stimulus If there are differrences in results, the lowest threshold is taken.

\section{Data Analysis}

The data will be analyzed descriptively to see the frequency distribution of the variables to be presented. Then inferential analysis was conducted to analyze the relationship of each independent variable to the dependent variable with the chi square test.

\section{Research Ethics}

The research was conducted in accordance with the ethical rules stipulated in the Helsinki declaration and obtained ethical clearance from the ethics committee of RS H Adam Malik Medan. 


\section{RESULTS}

This study was conducted from November 2019 to December 2019. In that time frame, 72 people were taken as samples in this study. All samples in this study were Table 1. Sample characteristics (categorical data)

\begin{tabular}{llcc}
\hline \multicolumn{1}{c}{ Characteristics } & \multicolumn{1}{c}{ Category } & Frequency & Percentage \\
\hline \multirow{2}{*}{ Age } & 45-59 years old & 39 & $54.2 .0 \%$ \\
& 60-74 years old & 33 & $45.8 .0 \%$ \\
Gender & Male & 58 & $80.6 \%$ \\
\multirow{3}{*}{ Presbycusis Type } & 14 & $19.4 \%$ \\
& Female & 33 & $45.9 \%$ \\
& Normal & 18 & $25 \%$ \\
& Strial type & 7 & $9.7 \%$ \\
& Neural Type & 7 & $9.7 \%$ \\
& Sensory Type & 7 & $9.7 \%$ \\
\hline
\end{tabular}

Table 1 shows the mean age of the subjects in the 45-59 years age group as many as 39 people (54.2\%) and the 60-74 years age group as many as 33 people (45.8\%). In this study, it shows that male patients aged $>50$ years at the Geriatric Polyclinic of Haji Adam Malik Hospital, Medan. The characteristics of the research subject can be seen in Table 1 .
Table 2. Determinants of Presbycusis (an analysis by Chi Square)

\begin{tabular}{|c|c|c|c|c|c|c|c|}
\hline \multirow{3}{*}{ Variable } & \multicolumn{4}{|c|}{ Presbycusis } & \multirow{3}{*}{$\mathbf{O R}$} & \multirow{3}{*}{$95 \% \mathrm{CI}$} & \multirow{3}{*}{$\mathbf{p}$} \\
\hline & \multicolumn{2}{|c|}{ No } & \multicolumn{2}{|r|}{ Yes } & & & \\
\hline & $\mathbf{N}$ & $\%$ & $\mathbf{N}$ & $\%$ & & & \\
\hline \multicolumn{8}{|l|}{ Blood Sugar Levels } \\
\hline Normal (<200 mg/dl) & 24 & 72.7 & 8 & 20.5 & \multirow{2}{*}{$3 \cdot 33$} & \multirow{2}{*}{1.81 to 6.13} & \multirow{2}{*}{$<0.001$} \\
\hline $\mathrm{DM}$ ( $\geq 200 \mathrm{mg} / \mathrm{dl})$ & 9 & 27.3 & 31 & 79.5 & & & \\
\hline \multicolumn{8}{|l|}{ Uric Acid Levels } \\
\hline Normal & 26 & 78.8 & 18 & 46.2 & \multirow{2}{*}{2.36} & \multirow[t]{2}{*}{1.19 to 4.70} & \multirow{2}{*}{0.005} \\
\hline High & 7 & 21.2 & 21 & 53.8 & & & \\
\hline \multicolumn{8}{|c|}{ Total Cholesterol Levels } \\
\hline Normal (<200 mg/dl) & 24 & 72.7 & 8 & 20.5 & & \multirow[t]{3}{*}{1.81 to 6.13} & \multirow[b]{2}{*}{$<0.001$} \\
\hline $\begin{array}{l}\text { Hypercholesterolemia } \\
(\geq 200 \mathrm{mg} / \mathrm{dl})\end{array}$ & 9 & $27 \cdot 3$ & 31 & 79.5 & 3.33 & & \\
\hline \multicolumn{7}{|l|}{ Smoking Habit } & \\
\hline Not smoking & 11 & $33 \cdot 3$ & 4 & 10.3 & \multirow{2}{*}{1.90} & 1.21 to 2.97 & \multirow{2}{*}{0.016} \\
\hline Smoking & 22 & 66.7 & 35 & 89.7 & & & \\
\hline
\end{tabular}

Table 2 shows that of the 39 subjects, it was found that $21(79.5 \%)$ people had presbycusis with $\mathrm{DM}(\mathrm{OR}=3.33$; 95\% $\mathrm{CI}=$ 1.81 to $6.13 ; \mathrm{p}$ <0.001). There were 21 (53.8\%) people with high uric acid levels who suffered from presbycusis $(\mathrm{OR}=2.36$; $95 \% \mathrm{CI}=1.19$ to $4.69 ; \mathrm{p}=0.005)$ and 31 subjects are more than female subjects, where the number of males is 58 people (80.6\%). Based on the type of presbycusis, there were at most 18 people (25\%) of the strial type.
(79.5\%) people with total cholesterol levels above $200 \mathrm{mg} / \mathrm{dl}(\mathrm{OR}=3.33 ; 95 \% \mathrm{CI}=1.81$ to $6.128 ; \mathrm{p}<0.001)$.

\section{DISCUSSION}

Presbycusis is a sensorineural hearing loss associated with age and is the most 
common cause of hearing loss in the elderly. Presbycusis consists of four types, namely: sensory, neural, metabolic or stria types, and cochlear conduction (Nuryadi et al., 2017). The incidence of presbycusis in the world varies based on the social rank of the population. Western and underdeveloped countries have a different picture of hearing loss (Busis, 2006; Roland, 2014; Cheslock and De Jesus, 2021).

The sensory type shows epithelial atrophy accompanied by loss of hair cells and cortiary organ support cells. The hallmark of the sensory presbycusis type is a sudden decrease in hearing at high frequencies (slooping). A typical feature of the sensory-type configuration is the noiseinduced hearing loss (NIHL) type, mostly in men with a history of noise. The neural type shows atrophy of nerve cells in the cohlea and central nervous pathways. On audiometry, there is a moderate hearing loss which is almost the same for all frequencies. The metabolic type occurs atrophy of the vascular stria at the apex of the cohlea. On audiometry there is a decrease in hearing with a flat image at all frequencies. The cohlear / mechanical conduction type is due to disturbance of mechanical movement in the basement membrane. The typical picture of an audiogram is descending and symmetrical (skiloop) (Muyassaroh, 2012; Cheslock and De Jesus, 2021).

The results of the description of the characteristics of this study indicate that the age of the respondents in the 45-59 years age group is 39 people (54.2\%) and the 60-74 years age group is 33 people (45.8\%) (Table 1). This is different in the study of Nuryadi et al (2017), where presbycusis was found to be most common in the 60-70 year age group as many as 23 patients (67.65\%). In Mondelli and Lopes (2009) study, it was stated that presbycusis was experienced by a population aged 65-75 years around $30-35 \%$ while in the population aged more than 70 years around 40$45 \%$. This is different from the study in Qatar which found the highest prevalence of presbycusis in the middle age group, namely 50-59 years (Benner et al., 2008). According to Loeb et al. (2005), as we age cell damage due to oxidative stress increases and accumulates over the years which eventually causes the aging process. Reactiveoxygen species (ROS) cause damage to mitochondrial mtDNA and cohlear tissue protein complexes resulting in hearing dysfunction.

The results of the study for gender showed that men suffered more from presbycusis, where the number of men was 58 people $(80.6 \%)$ and women were 14 people (19.4\%) (Table 1). This is in accordance with the research of Nuryadi et al. (2017), which found a sample of 26 patients $(76.47 \%)$ presbycusis, mostly in the male gender. However, in other studies there were no differences in race and sex (Wright, 2006). Gene research by the Translational Genomics Research Institute (TGen) in Santa Clara, California, and the University of Antwerp, Belgium did not explain why men were more susceptible to presbycusis, but they found one of the most prominent genes (GRM7) that produces glutamate and can cause damage to hair cells in and outside the ear due to aging, causing hearing loss (Friederman, 2009). Men experienced more hearing loss at high frequencies and only slightly decreased at low frequencies when compared to women. According to research by Kim et al. (2010) in South Korea stated that there was a decrease in the degree of hearing in women by $2 \mathrm{kHz}$ worse than men. The results of this study are consistent with the research of Cláudia Simônica de Sousa et al. (2009) in Brazil, $85.5 \%$ of patients with presbycusis were male and $14.5 \%$ female. Gender 
differences in the high frequency hearing threshold, because men are generally exposed to noise in the workplace more often than women. Kim et al. (2010) stated that differences in the effect of sex on presbycusis were not entirely due to changes in the cohlea. Women have smaller leaves and ear canals, which can cause a masking noise effect at low frequencies.

In this study, there were 18 people (strial type), 7 people (neural type), 7 people (sensory type), 7 people (cochlear type) (table 1). This is in accordance with the research of Nuryadi et al. (2017), where the most common type found in the male gender was the strial type in both ears, as many as 15 people on the right ear (57.69\%) and 13 people on the left ear (50\%), while the female The same results were obtained between the strial and cochlear conduction types, namely 4 people (50\%) in the right ear and in the left ear, 5 people (62.5\%) and cochlear conduction (37.5\%) were also found. The prevalence of metabolic presbycusis or strial presbycusis was quite high, namely metabolic $34.6 \%$, followed by other types, namely neural 30.7\%, mechanical $\mathbf{2 2 . 8 \%}$, sensory $11.9 \%$. This is presumably because the vascular stria contains a lot of vascularity, in the histopathological study of aging mice, there is vascular involvement between age and hearing loss (Wright, 2006; Gates \& Mills, 2005; Melinda et al., 2012).

The relationship between the incidence of presbycusis and an increase in blood sugar levels, and there was a significant relationship between the incidence of presbycusis and blood sugar levels ( $p$ <0.001) (table 2) Diabetes Mellitus (DM) can cause microangiopathy of the cochlear organ, can occur atrophy and decrease hair. Neuropathy in the VIII nerve vasa nervosum, ligaments and spiral ganglion is characterized by Schwann cell damage, myelin degeneration, and axon damage which results in decreased hearing (Frisina et al., 2006; Meneses-Barriviera et al., 2018). The relationship between DM and the incidence of hearing loss is still under debate, although in theory there is a link between hyperglycemia and hearing loss (Kakarlapudi, 2003). Benner et al. (2008) stated that there was a significant relationship between DM sufferers and hearing loss in the elderly, $\mathrm{p}=$ 0.034. With the increasing incidence of DM patients, it is very likely that presbycusis sufferers are also increasing, especially neural types compared to other types. Histologically, the neural type presbiacusis shows atrophy of spiral ganglion cells and cortiary organs, and in patients with diabetes mellitus (DM), glucose that is bound to proteins in the glycosylation process will form an advanced glicosilation end product (AGEP) which accumulates in the tissue and reduces wall elasticity. blood vessels (arteriosclerosis). The next process is that the walls of the blood vessels become thicker and the lumen narrows which is called microangiopathy. Microangiopathy in the cohlea will cause atrophy and reduced hair cells (Loeb, 2005; Maria \& Fernanda, 2009; Dhingra \& Deeksha, 2010).

In this study there was a relationship between the incidence of presbycusis and uric acid levels, and there was a significant relationship between the incidence of presbycusis and uric acid levels ( $p=0.005$ ) (Table 2). This is different from the study of ZhuWen-yan et al. (2009), said that uric acid has the potential to cause hearing loss. In the research of Sumule et al. (2016), it can be concluded that hyperuricemia can cause disruption of cochlear function which leads to hearing loss. In this study, it is still unclear how increased uric acid levels can cause hearing loss. Several theories have emerged. The most progressive theory is 
the induction of oxidative stress and inflammation in the cochlea by urate crystals (Abdelkader et al., 2019).

The incidence of presbycusis on total cholesterol levels, and there was a significant relationship between total cholesterol levels and the incidence of presbycusis ( $p$ $<0.001$ ) (Table 2). Hypercholesterolemia can cause thickening and loss of elasticity of arteries which results in narrowing of the lumen, called microangiopathy. As a result of cochlear organ microangiopathy, there will be atrophy and reduced hair cells, which can cause hearing loss (Frisina et al., 2006). The results of research by Melinda et al. (2012) found that hypercholesterolemia was not associated with presbycusis. This difference is probably because the amount of presbycusis with hypercholesterolemia does not differ much from the subjects who do not suffer from hypercholesterolemia.

The relationship between the incidence of presbycusis and smoking habits, and there was a significant relationship between the incidence of presbycusis and smoking habits $(\mathrm{p}=0.016)$ (Table 2). Cigarettes contain nicotine and carbon monoxide which have an ischemic effect. As a result of ischemia there is a disruption of oxygen supply to the cortiary organs resulting in hearing loss. Other effects can occur blood vessel spasm, blood viscosity, and arteriosclerotic (Laviolette \& Kooy, 2004). In the research of Melinda et al. (2012) found that smoking habits on presbycusis did not show any relationship, $\mathrm{p}=0.274$. In contrast to the research of Cruickshanks (1998), states that there is a relationship between smoking habits and hearing loss in the elderly.

This study states that there is a significant relationship between increased blood sugar levels, uric acid levels, total cholesterol levels, and smoking habits with the incidence of presbycusis.

\section{AUTHOR CONTRIBUTION}

Authors contribute to the concept, design, analysis, and discussion of data.

\section{DISCUSSION}

The authors declare that the study was conducted in the absence of any commercial or financial relationships that could be construed as a potential conflict of interest.

\section{FUNDING AND SPONSORSHIP}

This study was self-funded.

\section{ACKNOWLEDGEMENT}

Researchers want to show their gratitude to the Department of Health, Ear, Nose, Throat, Head and Neck Surgery, Faculty of Medicine, University of North Sumatra/ H Adam Malik Medan Hospital.

\section{REFERENCE}

Lee FS, Matthew LJ, Dubno JR, Mills JH (2006). Longitudinal study of puretone thresholds in older persons. Ear and Hearing. 26: 1-11. DOI:10.1097/00003446-200502000-00001.

Nuryadi NKR, Wiranadha M, Sucipta W (2017). Karakteristik pasien presbikusis di Poliklinik THT-KL RSUP Sanglah Denpasar tahun 2013-2014. Medicina. 48(1): 58-61. DOI:10.15562/medicina.v48i1.27

Kim SH, Lim EJ, Kim HS, Park JH, Jarng SS, Lee SH (2010). Sex differences in a cross sectional study of age-related hearing loss in Korean. Clin Exp Otorhinolaryngol. 3: 27-31. doi: 10.3342/ceo.2010.3.1.27.

Muyassarohzz (2012). Faktor Risiko Presbikusis (Presbytery Risk Factors). J Indon Med Assoc. 62(4):155-8. 
Manullang et al./ Factors Affecting Presbycusis on Audiogram Overview

https://doi.org/10.47830/jinma-vol.68.1-2018.

Roland PS (2014). Presbycusis. http://emedicine.medscape.com/article/8559 89.

Cheslock M, De Jesus O (2021). Presbycusis. In: StatPearls. from: https://www.ncbi.nlm.nih.gov/books/NBK55922 $\mathrm{o} /$.

Suwento R, Hendarmin H (2007). Gangguan pendengaran pada geriatri' (Hearing loss in geriatrics), Dalam: Soepardi EA, Iskandar $\mathrm{N}$, penyunting, 'Buku ajar ilmu kesehatan telinga hidung teng-gorok kepala leher. Edisi ke-6, Jakarta: Balai Penerbit FK UI.

Lalwani AK (2008). The Aging Inner Ear.

Dalam: Lalwani, A.K. Diagnosis and Treatment in Otolaryngology Head and Neck Surgery. The MacGraw-Hill Companies Inc. New York.

Bener A, Salahudin A, Darwish S, AlHamaq A, Gansan L (2008). Association between hearing loss and type 2 diabetes mellitus in elderly people in a newly developed society. Biomed Res, 19(3): 187-95. https://www.researchgate.net/publication/228742760.

Busis SN (2006). Presbycusis. Dalam: Calhoun $\mathrm{KH}$ and Eibling DE, penyunting, Geriatric Otolaryngology, New York: Taylor \& Francis Group.

Roland PS, Kutz Jr JW, Isaacson B (2014). Aging and the Auditory and Vestibular System. Dalam: Bailey BJ, penyunting. Head \& Neck Surgery-Otolaryngology. Philadelphia: Lippincott Williams and Wilkins.

Dhingra, Deeksha (2010). Diseases of Ear, Nose \& Throat. Edisi ke lima. Pittsburg: Elsevier.

Gates GA, Mills JH (2005). Presbycusis, Lancet, 366(9491): 111120. https://doi.org/10.1016/s0140-6736(05)67423-5.
Maria, Fernanda (2009). Relationship between hypertension and hearing loss otorhinolaryngology. Intl Arc. 20: 40-43.

Agarwal S, Mishra A, Jagade M, Kasbekar V, Nagle SK (2013). Effects of hypertension on hearing. Indian J Otolaryngol Head Neck Surg. 65(3): 614-618. doi:10.1007/s12070-013-0630-1.

Melinda, Muyassaroh, Zulfikar (2012). Faktor yang berpengaruh terhadap kejadian presbikusis di rumah sakit Dr Kariadi Semarang. ORLI. 42(1). DOI: https://doi.org/10.32637/orli.v$42 \mathrm{i} 1.39$.

Mondelli GC, Lopes CA (2009). Relationship between arterial hypertension and hearing loss. Intl Arch Otorhinolaryngol. 13: 63-68. Doi: http://www.arquivosdeorl.org.br/conteudo/acerv o_eng.asp? $\mathrm{Id}=590$.

Meneses-Barriviera CL, Bazoni JA, Doi MY, Marchiori LLM (2018). Probable association of hearing loss, hypertension and diabetes mellitus in the elderly. Int Arch Otorhinolaryngol, 22(4): 337-341. doi:10.1055/s-00371606644 .

Laviolette SR, Kooy VD (2004). The neurobiology of nicotine addiction: bridging the gap from molecules to behavior. Nature Rev Neurosci. 5: 55-65. doi: 10.1038/nrn1298.

Loeb LA, Wallace DC, Martin GM (2005). The mitochondrial theory of aging and its relationship to reactive oxygen species damage and somatic mtDNA mutations. ProcNatl Acad Sci USA. 102: 59-70. doi: 10.1073/pnas.0509776102

Wright JLW (2006). Presbyacusis. Dalam: Ballantyne J, Groves J, penyunting, Scott-Brown's Diseases of The Ear, Nose and Throat. Edisi ke-4, Butterworths. 
Friederman R (2009). Human genetic molecular. Human Molecular Genetics. 18(4): 785-796. https://doi.org/10.1093/hmg/ddn402.

Frisina ST, Mapes F, Kim SH (2006). Characterization ofhearing loss in aged type II diabetic. Hear Res. 211: 103-13. doi: 10.1016/j.heares.2005.09.002.

Sousa CS, Castro Júnior Nd, Larsson EJ, Ching TH (2009). Risk factors for presbycusis in a socio-economic middle-class sample. Braz J Otorhinolaryngol. 75: 530-6. https://pubmed.ncbi.nlm.nih.gov/19784422/.

Cruickshanks KJ, Klein R, Klein B, Wiley TL, NondahlDM, Tweed TS (1998). Cigarette smoking and hearing loss: The epidemiology of hearing loss study. JAMA, 279(21): 1715-19. doi: 10.1001/jama.279.21.1715.

Gates GA, Mills JH (2005). Presbycusis. Lancet. 366(9491): 1111-20. doi: 10.1016/So140-6736(05)67423-5.
Wen-yan Z, Yan-hong D, Wandong S, Lu W, Xia G (2009). Relationship between sudden sensorineural hearing loss and vascular risk factors. J Otology. 4(1): 55-58. Doi: https://doi.org/10.1016/S1672-2930(09)50009-8

Sumule NI, Kadir A, Savitri E (2016). Relationship between hyperuricemia with auditory disorder based on otoacoustic emission. Int J Sci Basic Appl Res. 27(2): 63-69. http://gssrr.org/index.php?journal=JournalOfBasicAnd Applied.

Abdelkader NM, El-Sebaie A, Mohamed EF (2019). Effect of chronic gout on hearing: A prospective study. Am J Med Medical Sci. 9(12): 493-498. doi:10.5923/j.ajmms.20190912.10. 